\title{
HPLC AND SPECTROPHOTOMETRIC STABILITY - INDICATING STUDY OF RALOXIFENE IN PURE FORM AND TABLETS
}

\author{
Khalid Abdel-Salam M. Attia \\ Analytical Chemistry Department, Faculty of Pharmacy, Al-Azhar University, Cairo, Egypt.
}

\section{ABSTRACT:}

Five simple, sensitive, accurate and precise methods were developed for determination of raloxifene (RLX) in pure form as well as in its pharmaceutical preparation. Method [A] is HPLC stability-indicating method, where the intact drug (RLX), the internal standard (methocarbamol) and RLX degradation products were separated using a YMC-pack ODS-AQ $\mathrm{C}_{18}$ column (150 mm X $4.6 \mathrm{~mm} \mathrm{ID,} 3 \mu \mathrm{m}$ particle size ) using acetonitrile-0.05 $\mathrm{M} \mathrm{KH}_{2} \mathrm{PO}_{4}$ adjusted to $\mathrm{pH} 2.5$ using $\mathrm{H}_{3} \mathrm{PO}_{4}(50: 50 \mathrm{v} / \mathrm{v})$ as a mobile phase at a flow rate $1 \mathrm{ml} / \mathrm{min}$. and UV detection at $280 \mathrm{~nm}$, where a good linearity was obtained in the range of $0.5-8 \mu \mathrm{gml}^{-}$ ${ }^{1}$.The LOD was $0.077 \mu \mathrm{g} \mathrm{ml}^{-1}$ and the LOQ was $0.258 \mu \mathrm{gml}^{-1}$. Method [B] depended on measurement of the difference absorbance $(\Delta \mathrm{A})$ of the drug in the presence of its degradate between solutions in methanolic $0.1 \mathrm{M} \mathrm{HCl}$ and $0.1 \mathrm{M} \mathrm{NaOH}$ at $285 \mathrm{~nm}$. Beer's low was obeyed in the range of $3-27 \mu \mathrm{gml}^{-1}$. LOD and LOQ were found to be 0.233 and $0.778 \mu \mathrm{g} \mathrm{ml}^{-}$ ${ }^{1}$, respectively. Method [C] is stability - indicating First-Derivative $\left({ }^{1} \mathrm{D}\right)$ for the determination of intact RLX in presence of its degradation product at $268 \mathrm{~nm}$ in the range of $3-18 \mu \mathrm{g} \mathrm{ml}^{-1}$ with LOD of $0.254 \mu \mathrm{g} \mathrm{ml}^{-}$and LOQ of $0.849 \mu \mathrm{g} \mathrm{ml}^{-1}$. Method [D] depended on ion pairing of RLX with eosin-Y dye at $\mathrm{pH} 3.5$ to produce red coloured complex measured at $545 \mathrm{~nm}$. Beer's low was obeyed in the range of $2-20 \mu \mathrm{gml}^{-1}$. LOD and LOQ were found to be 0.276 and $0.920 \mu \mathrm{g} \mathrm{ml}^{-1}$, respectively. Method [E] depended on ion pairing of RLX with bromothymol blue (BTB) dye at $\mathrm{pH} 2.6$ to form a chloroform-soluble coloured ion association complex. The formed complex could be extracted and measured at $420 \mathrm{~nm}$. Good agreement with Beer's low was found in the range of $4-28 \mu \mathrm{gml}^{-1}$. LOD and LOQ were found to be 0.633 and $2.110 \mu \mathrm{g} \mathrm{ml}^{-1}$, respectively. The percent recoveries $\pm \mathrm{RSD} \%$ of these methods were $100.83 \pm 0.920,100.24 \pm 0.724,100.15 \pm 0.586,100.26 \pm 0.383$ and $99.98 \pm 0.261$, respectively. The obtained results were compared with those of the reported method and no significant difference was observed regarding accuracy and precision.

\section{INTRODUCTION:}

Raloxifene hydrochloride (RLX), 6-Hydroxy-2-(p-hydroxyphenyl) benzo[b]thien-3-ylp-(2-piperidinoethoxy) phenyl ketone hydrochloride, is a second generation selective estrogen receptor modulator. It is a non-steroidal that belongs to the benzothiophene class of compounds. It is used in the treatment and prevention of osteoporosis and invasive breast cancer in postmenopausal women ( Martindale 35: The Complete Drug Reference CD and The Merck index 2006 ).

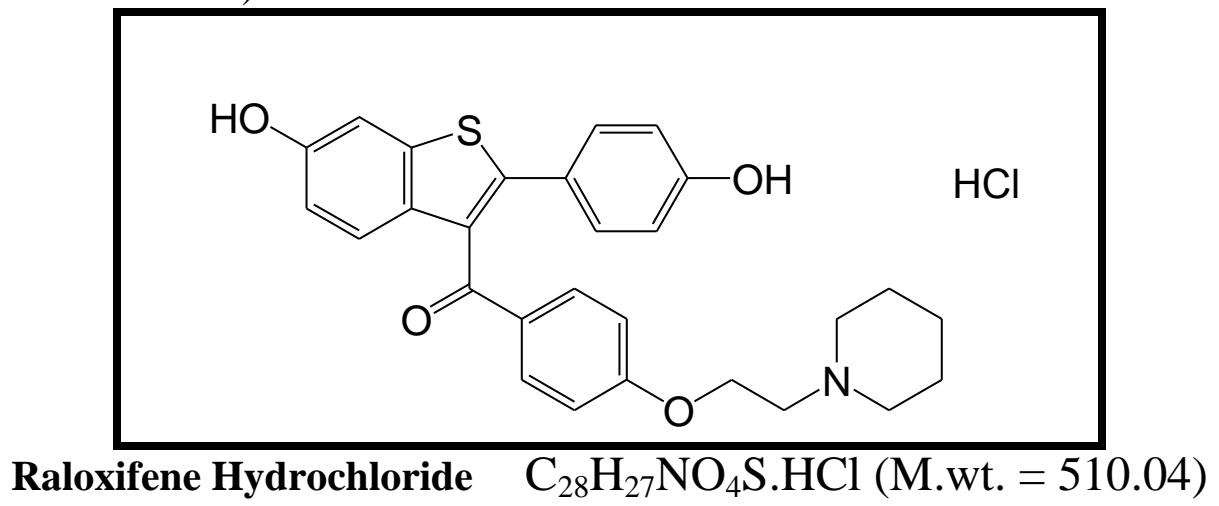


RLX is not official in any pharmacopoeia, but several methods have been reported for its determination in pure sample, pharmaceutical preparation and in biological fluids including spectrophotometric (Patel. et al., 2007; Pavithra and Lakshmi 2006; Dharuman et al., 2004; Annapurna et al. 2007; Basavaiah and Anil Kumar 2006; Basavaiah et al. 2008; Basavaiah et al., 2009; Kalyanaramu and Raghubabu 2011; Attia et al., 2009; Attia et al., 2009; Kalyanaramu and Raghubabu 2011; Kalyanaramu and Raghubabu 2011 and Kalyanaramu et al., 2011), spectrofluorimetric (Turij et al., 2007 and Turij et al., 2005), HPLC (Suneetha and Lakshmana Rao 2010; Jin 2004; Trontelj et al., 2005; Wang Q. et al., 2002; Nandini and Jayant 2001; Venkata et al., 2006; Pavithra and Lakshmi 2006; Chandorkar et al., 2006; Basavaiah et al., 2008; Santhyaraj et al., 2011; Madhu et al., 2011 and Vijaykumar et al., 2011), LC MS-MS (Trontelj et al., 2007 and Basavaiah K. et al., 2009), capillary electrophoresis (Perez-Ruiz et al., 2004), TLC densitometry (Shirkhedkar et al., 2012) and resonance rayleigh scattering (Li et al., 2002 and Shao et al., 2007). The main purpose of the present study is to stablish new simple, sensitive and validated methods for the determination of RLX in pure form and in its pharmaceutical dosage form.

\section{EXPERIMENTAL}

\section{Material}

\subsection{Pure Sample:}

Raloxifene hydrochloride was kindly supplied by South Egypt for Drugs and Industries Company (SEDICO), 6th October City, Egypt.

\subsection{Pharmaceutical Preparation:}

Evista $^{\circledR}$ Tablets, product of Lilly Company, Spain, batch No. A470499, labeled to contain $60 \mathrm{mg}$ RLX per tablet purchased from local market.

\section{Chemicals and Reagents:}

All chemicals and reagents used throughout the work were of analytical grade.Water used throughout the procedures was freshly distilled.

- Acetonitrile HPLC grade (Sigma;Aldrich, Germany; LabScan, Poland and Scharlau Chemie, Europian Union).

- Hydrochloric acid, anhydrous sodium acetate, Acetic acid, potassium chloride, potassium dihydrogen phosphate, sodium hydroxide, carbon tetrachloride, chloroform, ethylene chloride, methylene chloride, potassium acid phthalate and absolute ethanol ( El-Nasr Company., Egypt).

- Methanol ( Merck, Germany).

- Glacial acetic acid (Fisher Scientific, U.S.A).

- Phosphoric acid 85\% (peypin-France).

- Eosin-Y (Sigma; Aldrich, Germany).

- Bromothymol blue (BTB) ( Merck, Germany).

- $\quad 0.1 \mathrm{M}$ methanolic $\mathrm{HCl}$ and $0.1 \mathrm{M}$ methanolic $\mathrm{NaOH}$.

- $\quad$ Eosin-Y $\left(2 \times 10^{-3} \mathrm{M}\right),\left(3.13 \times 10^{-4} \mathrm{M}\right)$ and $\left(1.25 \times 10^{-4} \mathrm{M}\right)$ aqueous solution.

- BTB $0.1 \% \mathrm{w} / \mathrm{v}$ and $\left(9.8 \times 10^{-4} \mathrm{M}\right)$ prepared by dissolving in the least amount of ethanol and completing to volume with water.

- $0.05 \mathrm{M}$ potassium dihydrogen phosphate.

- $\quad 0.2 \mathrm{M}$ potassium chloride.

- $\quad 1 \mathrm{M}$ and $0.2 \mathrm{M}$ aqueous solution hydrochloric acid.

- $1 \mathrm{M}$ aqueous solution sodium hydroxide. 
- Acetate buffer ( pH 2.5 - 4.4) (British Pharmacopoeia, 2001).

- $\quad$ Phthalate buffer ( $\mathrm{pH} 2.2$ - 4) and HCl-buffer ( $\mathrm{pH} 1.2$ - 2)( United States Pharmacopoeia XXIII, 1995).

\section{Apparatus:}

- Shimadzu UV-Vis. 1650 Spectrophotometer, Japan.

- Perkin Elmir series 200 manual HPLC equipped with quaternary pump and total Chrom station software.

- UV lamp with short wavelength (254nm).

- Precoated TLC plates silica gel 60 GF254 (20 x20 cm), 0.22mm thickness (Fluka, Chemie, Switzerland).

- pH meter 3510, Jenway.

- Hot plate, torrey pines scientific, USA.

- FT-IR, Nicolet IR 200, Thermo electron corporation

- NMR, mercury-300 BB (NMR300).

\section{Standard Solutions:}

\subsection{Standard solution of intact drug ( RLX):}

\subsubsection{For method A (HPLC Technique):}

Stock solution of the drug $\left(0.1 \mathrm{mg} \mathrm{ml}^{-1}\right)$ was prepared by dissolving $10 \mathrm{mg}$ powder in the least amount of methanol then completing the volume to $100 \mathrm{ml}$ with mobile phase. Stock solution of methocarbamol as internal standard $\left(0.05 \mathrm{mg} \mathrm{ml}^{-1}\right)$ was prepared by dissolving 5 $\mathrm{mg}$ in $100 \mathrm{ml}$ methanol.

\subsubsection{For method $B(\Delta A$ Technique):}

Two stock solutions of RLX $\left(0.1 \mathrm{mg} \mathrm{ml}^{-1}\right)$ were prepared by dissolving $10 \mathrm{mg}$ powder in $100 \mathrm{ml}$ of $0.1 \mathrm{M}$ methanolic $\mathrm{HCl}$ and $100 \mathrm{ml}$ of $0.1 \mathrm{M}$ methanolic $\mathrm{NaOH}$.

\subsubsection{For method C (First-Drivative Technique):}

Standard solution of RLX $\left(0.05 \mathrm{mg} \mathrm{ml}^{-1}\right)$ was prepared by dissolving $5 \mathrm{mg}$ of the drug in methanol and completing the volume to $100 \mathrm{ml}$ with the same solvent.

\subsubsection{For methods D and E (Ion-Pair Technique):}

$10 \mathrm{mg}$ of RLX powder was accurately weighed and transferred into $100 \mathrm{ml}$ volumetric flask, then dissolved in the least amount of ethanol, the volume was completed to the mark with water to obtain $\left(0.1 \mathrm{mg} \mathrm{ml}^{-1}\right)$. The working solution was prepared by diluting with water.

\subsection{Standard solution for degradated sample:}

$50 \mathrm{mg}$ of pure RLX powder were refluxed with $50 \mathrm{ml} 1 \mathrm{M} \mathrm{HCl}$ for 36 hours. After cooling the solution was neutralized by $1 \mathrm{M} \mathrm{NaOH}$, evaporated to dryness under vacuum, the residue was extracted three times with $25 \mathrm{ml}$ methanol, filtered into $100 \mathrm{ml}$ volumetric flask then the volume was adjusted by methanol. The obtained solution labeled to contain the degradation product derived from $\left(0.5 \mathrm{mg} \mathrm{ml}^{-1}\right)$ of RLX.

\section{Procedures:}

\subsection{Analysis of standard solution}

\subsubsection{For method A (HPLC Technique):}

At ambient temperature, isocratic separation was carried out on YMC-Pack ODS-AQ $\mathrm{C}_{18}$ column ( $150 \mathrm{X} 4.6 \mathrm{~mm}$ ID X $3 \mu \mathrm{m}$ ) using a mobile phase consists of acetonitrile and 0.05 
M KH${ }_{2} \mathrm{PO}_{4}$ adjusted to $\mathrm{pH} 2.5$ by using $\mathrm{H}_{3} \mathrm{PO}_{4}(50: 50 \mathrm{v} / \mathrm{v}$ ). The mobile phase was degassed by a degasser before pumped at flow rate $1 \mathrm{ml} \mathrm{min}^{-1}$, before injecting the solutions, the column was equilibrated for at least 30 minutes with the mobile phase flowing through the system. The injected volume of the standard solution was $20 \mu 1$ and UV detection at $280 \mathrm{~nm}$. Aliquots of drug solution $\left(100 \mu \mathrm{g} \mathrm{ml}^{-1}\right)$ corresponding to $\left(5-80 \mu \mathrm{g} \mathrm{ml}^{-1}\right)$ of RLX were transferred into series of $10 \mathrm{ml}$ volumetric flasks containing ( $50 \mu \mathrm{g})$ of internal standard and adjusted to volume with the mobile phase. Calibration curve was constructed by plotting the peak area ratio versus the corresponding drug concentration in $\mu \mathrm{g} \mathrm{ml}^{-1}$.

\subsubsection{For method $B(\Delta A$ Technique):}

In a series of $50 \mathrm{ml}$ volumetric flasks, aliquots of RLX $\left(0.1 \mathrm{mg} \mathrm{ml}^{-1}\right)$ equivalent to (3$27 \mu \mathrm{g} \mathrm{ml}^{-1}$ ) were transferred and completed to the mark with $0.1 \mathrm{M}$ methanolic $\mathrm{HCl}$ solution. In another series of $50 \mathrm{ml}$ volumetric flasks, the same volumes of drug solution were transferred and completed to the mark with $0.1 \mathrm{M}$ methanolic $\mathrm{NaOH}$ solution. The acidic drug solutions were measured at $285 \mathrm{~nm}$ against the alkaline drug ones and the calibration graph was constructed.

\subsubsection{For method C (First - Derivative Technique):}

Aliquots of standard RLX solution in methanol $\left(0.05 \mathrm{mg} \mathrm{ml}^{-1}\right)$ containing $0.03-0.18$ $\mathrm{mg}$ of the drug were added to a series of $10 \mathrm{ml}$ volumetric flasks and then diluted to the mark with methanol. First-derivative $\left({ }^{1} \mathrm{D}\right)$ spectra of the drug were recorded against methanol as a blank. The height of the peak at $268 \mathrm{~nm}$ was measured in $\mathrm{cm}$ for each drug concentration.

\subsubsection{For method D (Ion-Pair Technique with Eosin-Y):}

Aliquots of drug solution of $\left(0.05 \mathrm{mg} \mathrm{ml}^{-1}\right)$ containing $(0.02-0.2 \mathrm{mg})$ were transferred into a series of $10 \mathrm{ml}$ volumetric flasks; the volumes were diluted to $8 \mathrm{ml}$ with water. Eosin-Y $0.4 \mathrm{ml}$ of $\left(2 \times 10^{-3} \mathrm{M}\right)$ solution was then added and the mixture was mixed well before addition of $1.2 \mathrm{ml}$ of acetate - buffer $\mathrm{pH} 3.5$. The mixture was adjusted to the volume with water and the solution was allowed to stand for 10 minutes at room temperature, then the absorbance was measured at $545 \mathrm{~nm}$ against the reagent blank.

\subsubsection{For method E (Ion-Pair Technique with BTB):}

Into a series of $125 \mathrm{ml}$ separating funnels, transfer aliquot portions of the standard drug solution $\left(0.1 \mathrm{mg} \mathrm{ml}^{-1}\right)$ containing $(0.1-0.7 \mathrm{mg})$, then add $4 \mathrm{ml}$ of phthalate buffer $\mathrm{pH} 2.6$ followed by $3 \mathrm{ml}$ of BTB (0.1\%).Adjust the total volume of the aqueous phase to $15 \mathrm{ml}$ by the addition of water, then shake the contents for about one minute. Extract with two successive portions each of $10 \mathrm{ml}$ chloroform, collecting the extract into a $25 \mathrm{ml}$ volumetric flask. Complete to volume with chloroform and measure the absorbance at $420 \mathrm{~nm}$ against the reagent blank.

\subsection{Analysis of pharmaceutical preparation:}

For method A, five tablets of Evista ${ }^{\circledR} 60 \mathrm{mg}$ were weighed and finely powdered, then an accurately weighed amount of powder equivalents to $10 \mathrm{mg}$, dissolved in the least amount of methanol, then completing the volume to $50 \mathrm{ml}$ with mobile phase, filtered into $100 \mathrm{ml}$ volumetric flask and the volume was completed with the mobile phase. The obtained solution labeled to contain $\left(0.1 \mathrm{mg} \mathrm{ml}^{-1}\right)$ of RLX. The solution was analyzed following the proposed procedure. In method B, two extractions were made, the first by transfering a quantity of the powder equivalent to $10 \mathrm{mg}$ to $100 \mathrm{ml}$ volumetric flask and shaked with $50 \mathrm{ml}$ of $0.1 \mathrm{M}$ methanolic $\mathrm{HCl}$ for about 15 minutes, filtered then the volume was completed to the mark with methanol. While the second one was done by transferring the same quantity of the powder to $100 \mathrm{ml}$ volumetric flask and shaked with $50 \mathrm{ml}$ of $0.1 \mathrm{M}$ methanolic $\mathrm{NaOH}$ for 
about 15 minutes, filtered then the volume was completed to the mark with methanol. Analyze aliquots of the clear filterate labeled to contain $0.1 \mathrm{mg} \mathrm{ml}^{-1}$.In method $\mathbf{C}$, an accurately weighed portion of Evista ${ }^{\circledR} 60 \mathrm{mg}$ very fine powdered tablets equivalent to $5 \mathrm{mg}$ of RLX was extracted three times with $25 \mathrm{ml}$ methanol, filtered into $100 \mathrm{ml}$ volumetric flask then the volume was adjusted with the same solvent. Aliquots of the obtained solution containing $(0.03-0.18 \mathrm{mg})$ of RLX were analyzed by measuring the height of the peak in $\mathrm{cm}$ at $268 \mathrm{~nm}$ for each drug concentration by adopting the proposed ${ }^{1} \mathrm{D}$ procedure. Finally for methods D \& E, an accurately weighed quantity of the well-mixed powdered Evista ${ }^{\circledR} 60 \mathrm{mg}$ tablets equivalent to $10 \mathrm{mg}$ of RLX was shaken with $50 \mathrm{ml}$ ethanol for 15 minutes and filtered into $100 \mathrm{ml}$ volumetric flask then the volume was adjusted with water. The obtained RLX solution $\left(0.1 \mathrm{mg} \mathrm{ml}^{-1}\right)$ was subjected to colorimetric determination by the proposed methods.

\section{RESULTS AND DISCUSSION}

\section{Degradation of Raloxifene:}

Accelerated degradation of RLX was achieved upon heating under reflux with $1 \mathrm{M}$ hydrochloric acid for 36 hours. The degradate formation illustrated in the following scheme:

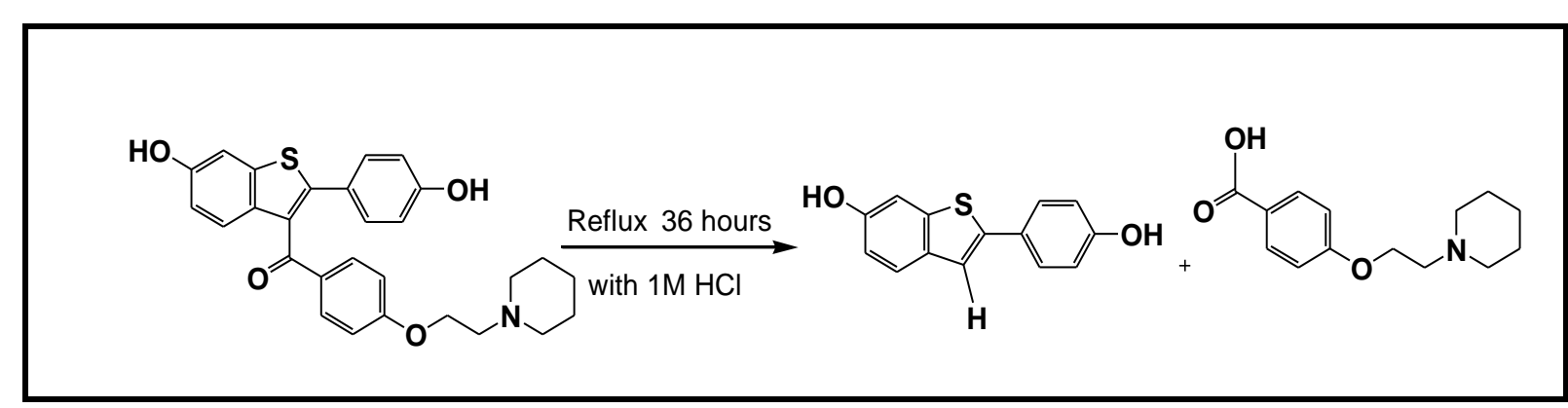

\section{Confirmation of degradation product:}

For isolation of RLX degradation product from the reaction medium, the solution after reflux with $1 \mathrm{M}$ hydrochloric acid for 36 hours was cooled, neutralized with $1 \mathrm{M}$ sodium hydroxide, evaporated under vacuum till dryness and extracted with methanol. The obtained solution was tested by TLC on silica gel $60 \mathrm{GF}_{254}$ plates. Separation of the intact drug and its corresponding degradate was achieved by using mobile phase consists of methanol chloroform $(6.5: 3.5 \mathrm{v} / \mathrm{v})$ and UV detection at $254 \mathrm{~nm}$. $\mathbf{R}_{\mathbf{f}}$ values of intact RLX and its corresponding degradate were 0.603 and 0.776 , respectively.

IR spectrum of the intact drug showed broad bands at $3140 \mathrm{~cm}^{-1}$ due to the $\mathrm{OH}$ groups. Also, a ketone group at $1641 \mathrm{~cm}^{-1}$ and at $1463 \mathrm{~cm}^{-1}$ for $\mathrm{C}=\mathrm{C}$ aromatic. While the IR spectrum of the degradate showed a broad band at $3434 \mathrm{~cm}^{-1}$ due to $\mathrm{OH}$ group of a carboxylic acid. Also, a band at $1702 \mathrm{~cm}^{-1}$ of the $\mathrm{C}=\mathrm{O}$ group, as shown in Figures $(\mathbf{1 , 2})$.

${ }^{1} \mathrm{HNMR}$ spectrum of the intact drug showed signals at 1.31 broad multiplet of $2 \mathrm{H}$, 1.62 multiplet of $4 \mathrm{H}$ and at 1.72 triplet of $4 \mathrm{H}$ for the piperidine ring. Then, at 2.91 triplet of $2 \mathrm{H}$ and 4.37 of $2 \mathrm{H}$ for ethoxy group. Also, signals between $6.64: 7.67$ multipet for $11 \mathrm{H}$ aromatic and at 9.8 for $1 \mathrm{H}$ of phenolic $\mathrm{OH}$ group. Finally a singlet signal at 10.2 for the phenolic $\mathrm{OH}$ group in benzothiophene moity. While the degradate showed signals for the piperidine ring as multiplet of $2 \mathrm{H}$ at 1.31 , triplet of $4 \mathrm{H}$ at 1.42 and 1.64 . Also, a broad band of $2 \mathrm{H}$ overlapping with DMSO at 2.47 and at 4.03 of $2 \mathrm{H}$ in the ethoxy group. $4 \mathrm{H}$ aromatic appear as multiplet between $6.64: 7.61$, moreover, a hump at 9.9 indicating $1 \mathrm{H}$ of $\mathrm{COOH}$ group, as shown in Figures $(\mathbf{3}, \mathbf{4})$. 


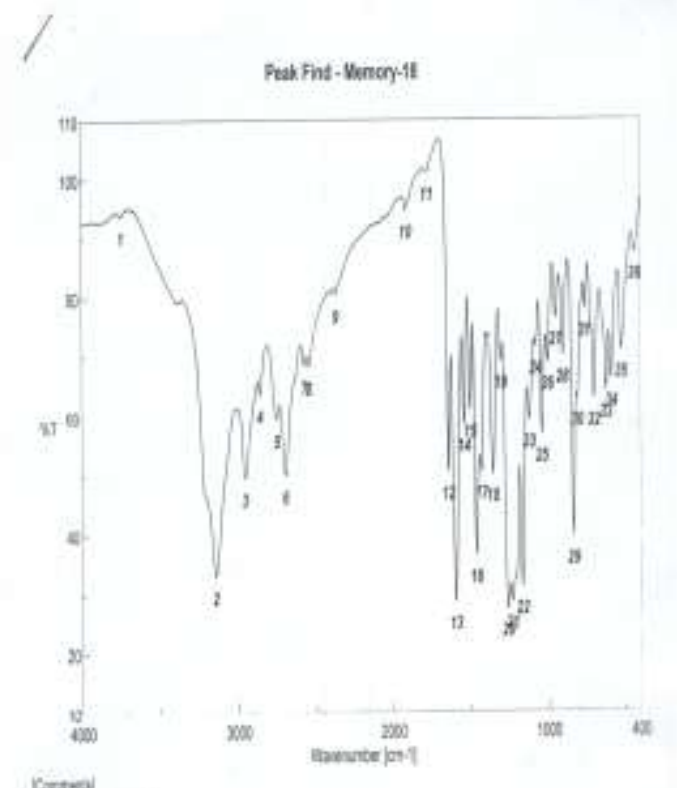

Figure (1): IR Spectrum of Intact Raloxifene on KBr Disc

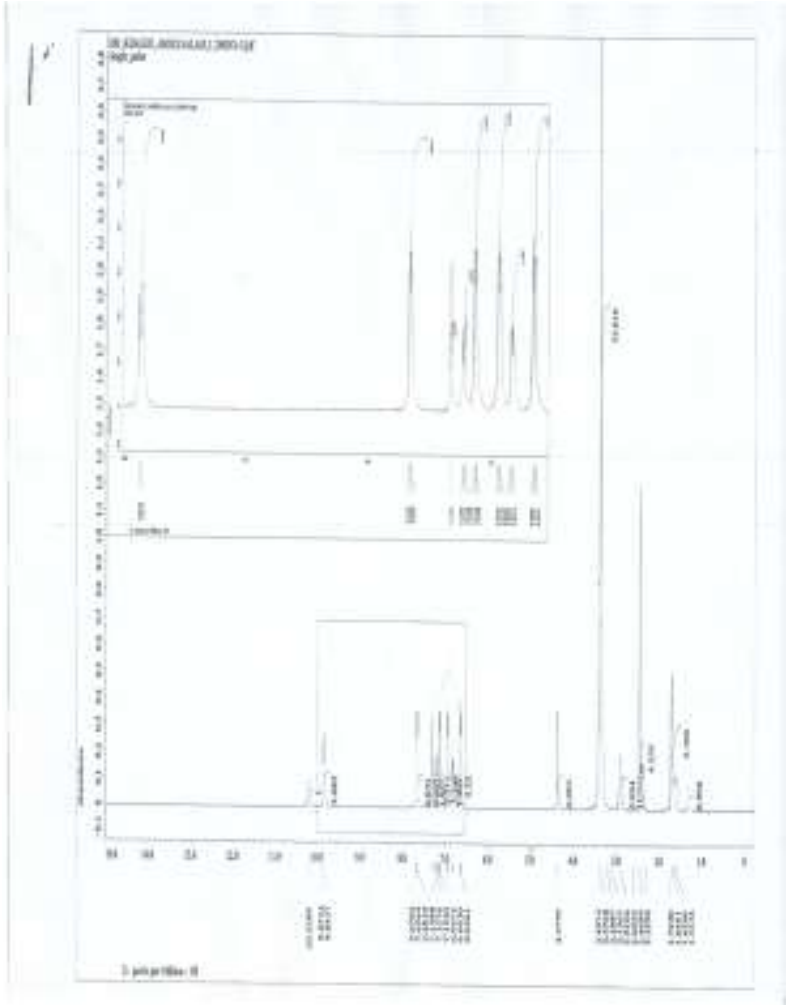

Figure (3): ${ }^{1} \mathrm{HNMR}$ Spectrum of intact Raloxifene in Deuterated DMSO.

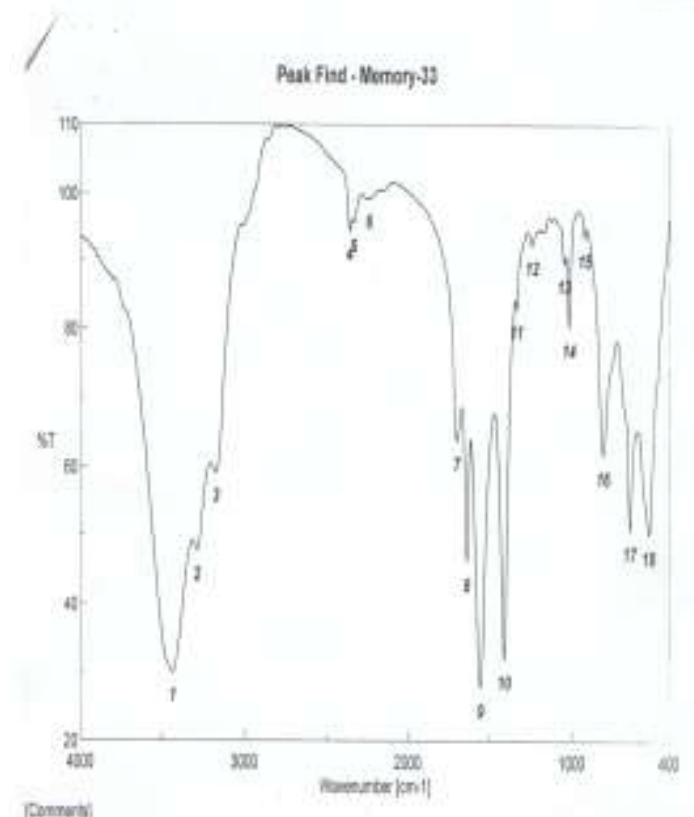

Figure (2): IR Spectrum of Degradated Raloxifene on KBr Disc.

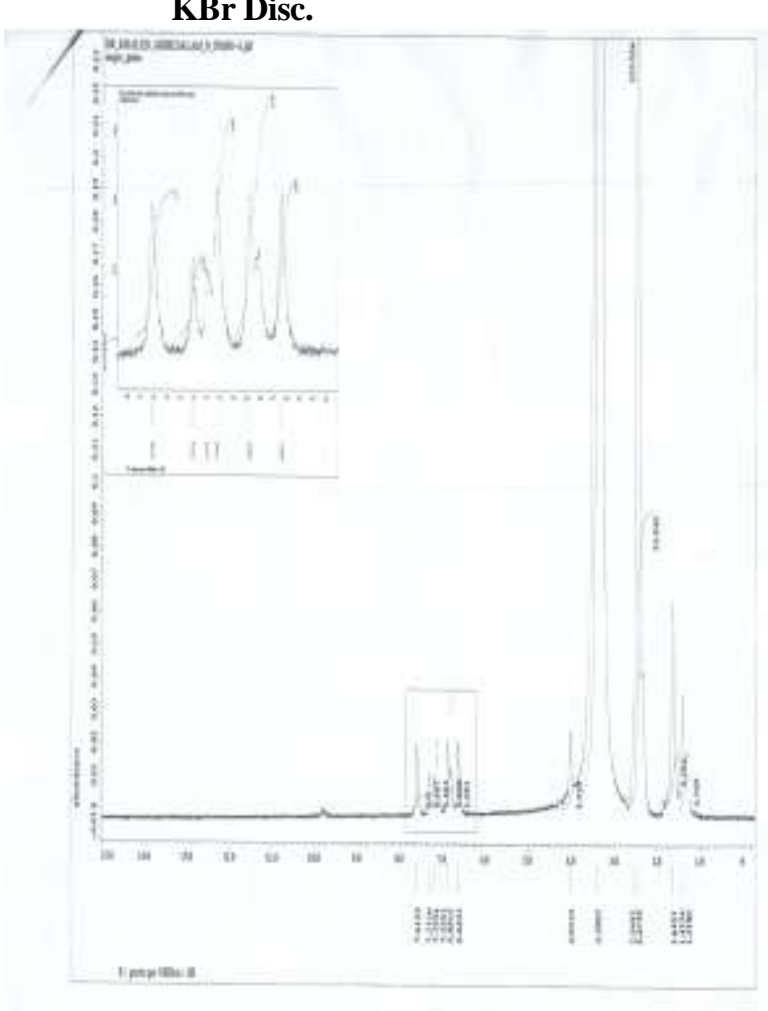

Figure (4): ${ }^{1}$ HNMR Spectrum of Degradated Raloxifene in Deuterated DMSO.

\section{In method A (HPLC Technique):}

RLX was selectively determined in presence of its degradation product using HPLC procedure. A simple and sensitive reversed phase HPLC procedure was suggested for the selective quantitative determination of RLX in presence of its degradation product. Different chromatographic conditions affecting the chromatographic separation were optimized after taking in consideration the resolution between the drug, its degradation product and the internal standard. Several mobile phases were tried in order to separate the intact drug from 
it's degradate and the internal standard including acetonitrile : $0.05 \mathrm{M} \mathrm{KH}_{2} \mathrm{PO}_{4}$ adjusted to $\mathrm{pH}$ 2.5 using orthophosphoric acid $85 \%$ in different ratios. Good separation was carried out on YMC-Pack ODS-AQ $\mathrm{C}_{18}$ column ( $150 \mathrm{X} 4.6 \mathrm{~mm}$ ID X $3 \mu \mathrm{m}$ ) using a mobile phase consists of acetonitrile and $0.05 \mathrm{M} \mathrm{KH}_{2} \mathrm{PO}_{4}$ adjusted to $\mathrm{pH} 2.5$ using $\mathrm{H}_{3} \mathrm{PO}_{4}(50: 50 \%$ ) at flow rate

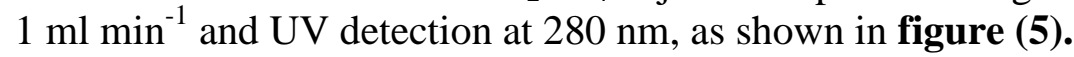

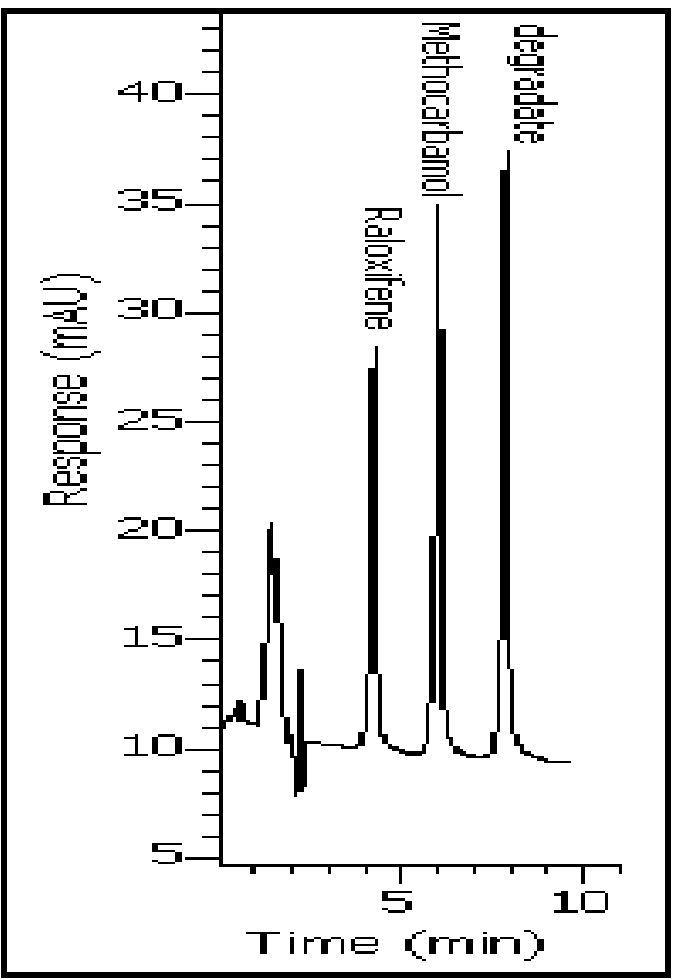

Figure(5): HPLC Chromatogram of Mixture of Intact Raloxifene $\left(2 \mu \mathrm{g} \mathrm{ml}^{-1}\right)$, Degraded Specificity: Raloxifene $\left(5 \mu \mathrm{g} \mathrm{ml}^{-1}\right)$ and Methocarbamol as Internal Standard $\left({ }^{\circ} \mu \mathrm{g} \mathrm{ml}^{-1}\right)$

The specificity of the proposed method was assured by applying the laboratory prepared mixtures of the intact drug together with its degradation product. The proposed method was adopted for the specific determination of intact RLX in presence of up to $87.5 \%$ of its corresponding degradate. The percentage recovery \pm SD $\%$ was $100.37 \pm 1.260 \%$, table (2).

\section{For method B ( $\Delta \mathrm{A}$ Technique):}

The change in the absorbance of only the intact RLX between the acid and alkaline media could be used for the determination of the intact drug in presence of its degradate. Absorbance difference measurements of both intact RLX and its degradate between $0.1 \mathrm{M}$ methanolic hydrochloric acid and $0.1 \mathrm{M}$ methanolic sodium hydroxide at $285 \mathrm{~nm}$ was used for the determination of the intact drug in presence of its degradate, where the $(\Delta \mathrm{A})$ of the later equals to zero at this $\lambda_{\text {max, }}$ as shown in figures $(6,7)$. 


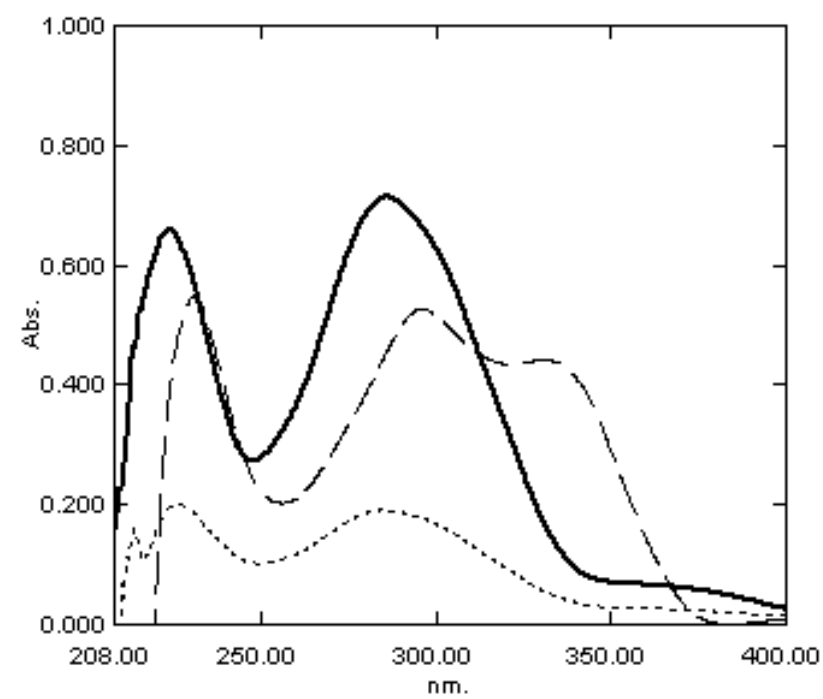

Figure(6): UV- Spectra of Intact Raloxifene $(6 \mu \mathrm{g}$ $\left.\mathrm{ml}^{-1}\right)$ in $0.1 \mathrm{~N} \mathrm{HCL}(-), 0.1 \mathrm{~N} \mathrm{NaOH}$ $(--)$ and their Difference $\Delta \mathrm{A}(\ldots .$.$) .$

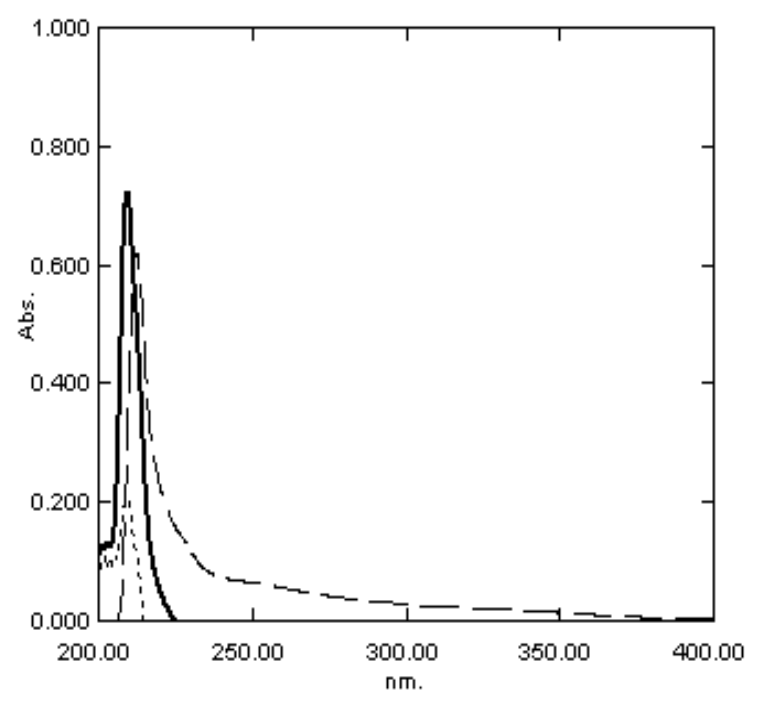

Figure(7): UV- Spectra of Degradated Raloxifene $\left(6 \mu \mathrm{g} \mathrm{ml}^{-1}\right)$ in $0.1 \mathrm{~N} \mathrm{HCL}(-), 0.1 \mathrm{~N}$ $\mathrm{NaOH}(--)$ and their Difference $\Delta \mathrm{A}(\ldots .$.$) .$

\section{Specificity:}

The specificity of the proposed procedure was assured by applying it to laboratory prepared mixtures of the intact drug together with its degradation product. The proposed procedure was adopted for the selective determination of intact RLX in presence of up to $77.7 \%$ of its corresponding degradate. The percentage recovery \pm SD $\%$ was $100.01 \pm 0.724 \%$, table (3).

\section{For method C ( ${ }^{1} \mathrm{D}$ Technique):}

The zero-order spectra of intact RLX and its degradation product show severe overlapping as shown in figure (8). However, this sever overlapping in zero-order spectra can be resolved by conversion of zero-order to higher first derivative spectra of RLX and its degradation product. Figure (9) showing that, the sever overlapping in zero-order spectra can be resolved at $268 \mathrm{~nm}$, at this wavelength zero cross point of degradation product showing no interference to intact RLX. So that, the peak at this wavelength was chosen for selective determination of the intact drug in presence of its degradate. At the described wavelength linear relationship was obtained between the peak in $\mathrm{cm}$ and the RLX concentration in the range $\left(3-18 \mu \mathrm{g} \mathrm{ml}^{-1}\right)$.

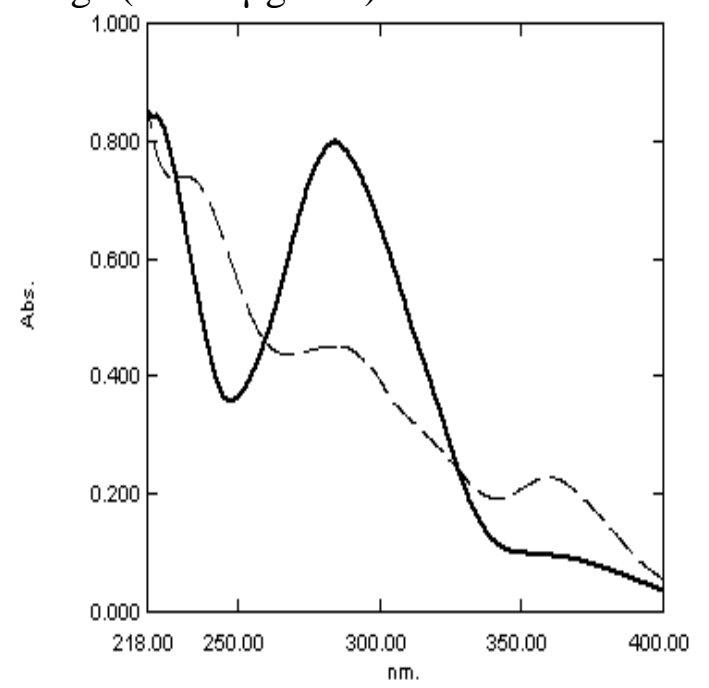

Figure(8): Zero-order Spectra of Intact Raloxifene $\left(6 \mu \mathrm{g} \mathrm{ml}^{-1}\right)(-)$ and its Degradation Product $\left(6 \mu \mathrm{g} \mathrm{ml}^{-1}\right)(--)$ in Methanol.

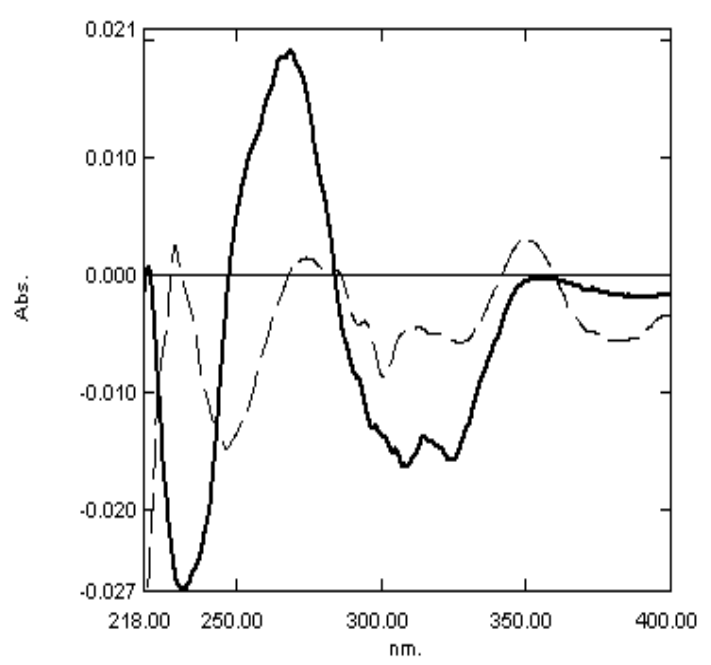

Figure (9): First-order Spectra of Intact Raloxifene $\left(6 \mu \mathrm{g} \mathrm{ml}{ }^{-1}\right)(-)$ and its Degradation Product $\left(6 \mu \mathrm{g} \mathrm{ml}^{-1}\right)(--)$ in Methanol. 


\section{Specificity:}

The specificity of the proposed method was assured by applying the laboratory prepared mixtures of the intact drug together with its degradation product. The proposed method was adopted for the specific determination of intact RLX in presence of up to $88.8 \%$ of its corresponding degradate. The percentage recovery \pm SD $\%$ was $100.28 \pm 0.801 \%$, table (4).

\section{For method D (Ion-Pair Technique with Eosin-Y):}

Eosin-Y dye is an anionic halofluorescein derivative that strongly associated with raloxifene in acidic medium to form ion pair associate.

This ion-pair associate of the studied drug with the anion of the halofluorescein dye (eosin - Y) was slightly soluble in water, but under the optimized experimental conditions, it become freely soluble and did not need an extraction into organic solvents nor the addition of non-ionic surfactants. This complex was probably formed via the electrostatic interaction between the maximally protonated terminal amino group of the drug (the most basic center in the drug molecule) and the carboxylate anion of the dye. This might primarily occur in acidic solutions (pH 1.2-4.4)( El-Brashy A M. et al. 2004) as shown in the following scheme:

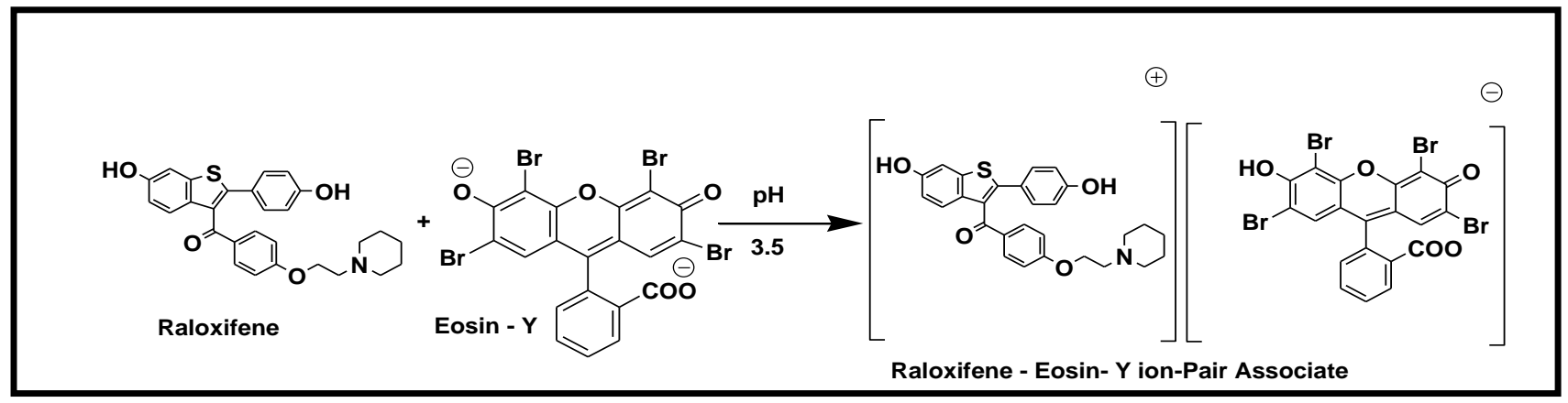

Raloxifene reacts with eosin-Y dye to form a highly red coloured ion-pair associate that exhibits an absorption maximum at $545 \mathrm{~nm}$ as shown in figure (10). Different parameters involved in the reaction were studied such as $\mathrm{pH}$, buffer volume, concentration of the reagent, reaction time and colour stability. The effect of $\mathrm{pH}$ of the medium as well as the buffer volume were studied and revealed that $1.2 \mathrm{ml}$ of $\mathrm{pH} 3.5$ acetate buffer were sufficient to give maximum absorbance figures $(\mathbf{1 1}, \mathbf{1 2})$. The effect of eosin - Y volume was also studied, figure (13) revealed that, $0.4 \mathrm{ml}$ of $\left(2 \times 10^{-3} \mathrm{M}\right)$ were sufficient to give maximum absorbance. The maximum color intensity for eosin-Y was attained after 10 minutes at room temperature and remained stable for further one hour. Heating at high temperatures had no effect on the rate of reaction; conversely, it caused complex breakdown and weakened the color intensity. Therefore, the room temperature was chosen as optimum for the assay procedure.

Molar ratio and continuous variation (Job's) methods were applied for determination of stoichiometry of the reaction of RLX with eosin-Y. Drug : reagent ratio was found to be $1: 1$, as shown in figures $(\mathbf{1 4}, \mathbf{1 5})$. 

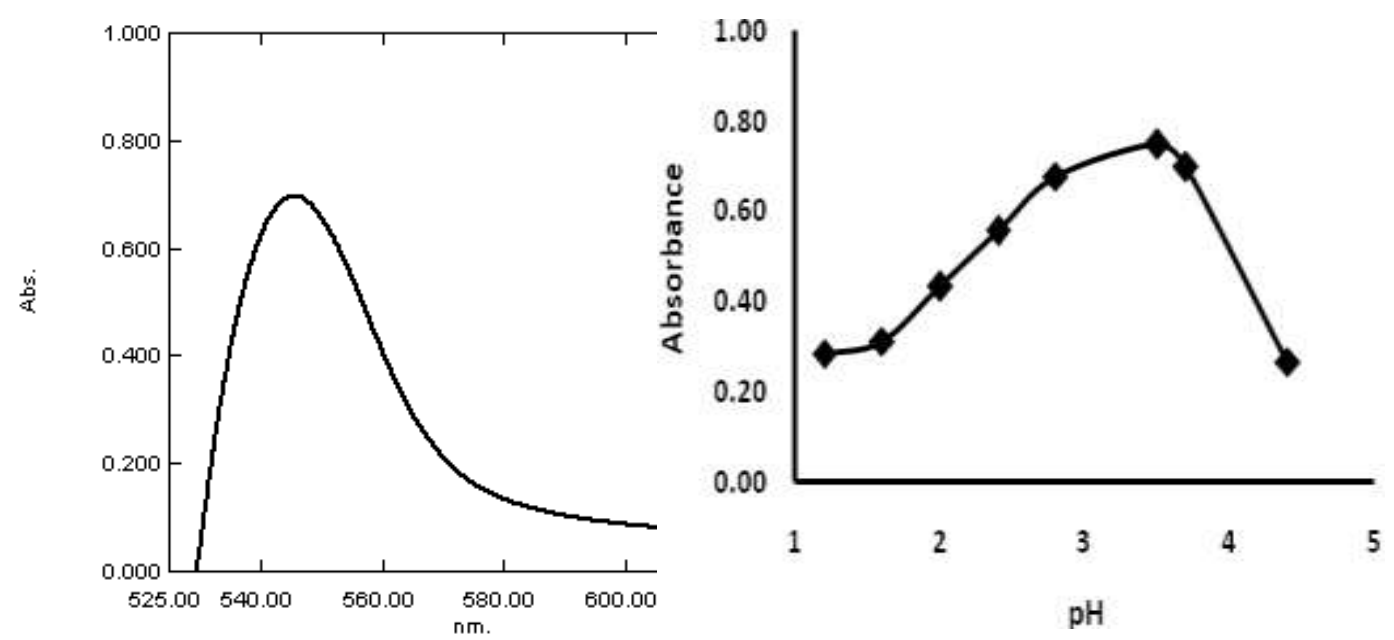

Figure (10): Absorption Spectrum of Raloxifene $\left(16 \mu \mathrm{gml}^{-1}\right)$ Reaction Product with $0.4 \mathrm{ml}$ Eosin -Y Dye.

Figure (11): Effect of $\mathrm{pH}$ on The Absorbance of Raloxifene ( $\left.16 \mu \mathrm{g} \mathrm{ml}^{-1}\right)$ Reaction Product with Eosin - Y at 5 $\leqslant 0 \mathrm{~nm}$.
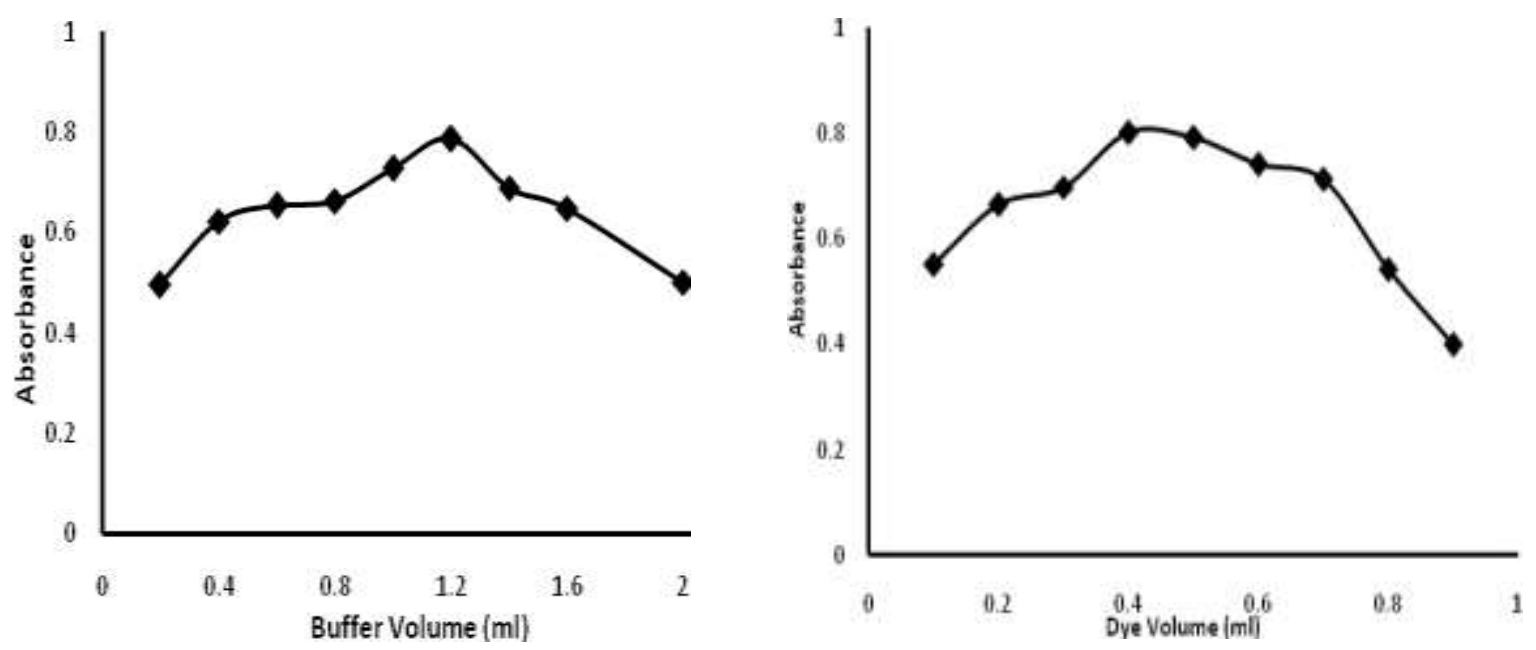

Figure (12): Effect of Buffer Volume on the absorbance of Raloxifene $\left(16 \mu \mathrm{g} \mathrm{ml}^{-1}\right)$ Reaction Product with Eosin - Y at $545 \mathrm{~nm}$.

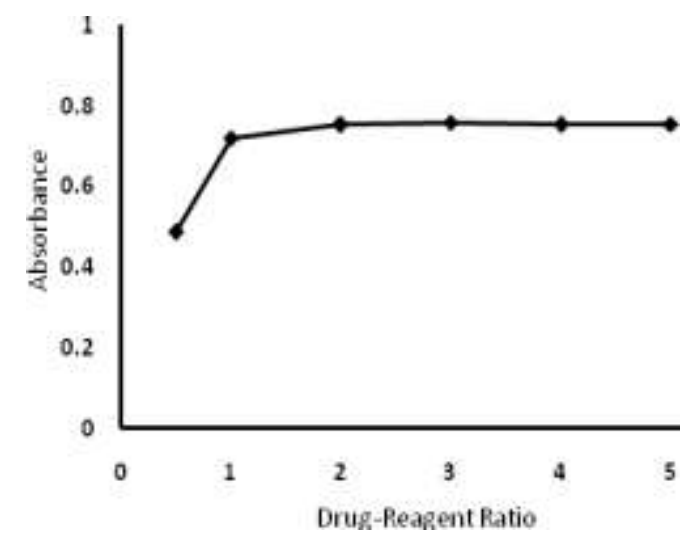

Figure (14): Stoichiometry of the Reaction of Raloxifene $\left(3.13 \times 10^{-4} \mathrm{M}\right)$ with Eosin$\mathrm{Y}\left(3.13 \times 10^{-4} \mathrm{M}\right)$ by Molar Ratio Method at $54^{\circ} \mathrm{nm}$.

Figure (13): Effect of Eosin - Y Volume on The Absorbance of Raloxifene $\left(16 \mu \mathrm{g} \mathrm{ml}^{-1}\right)$ Reaction Product at $54^{\circ} \mathrm{nm}$.

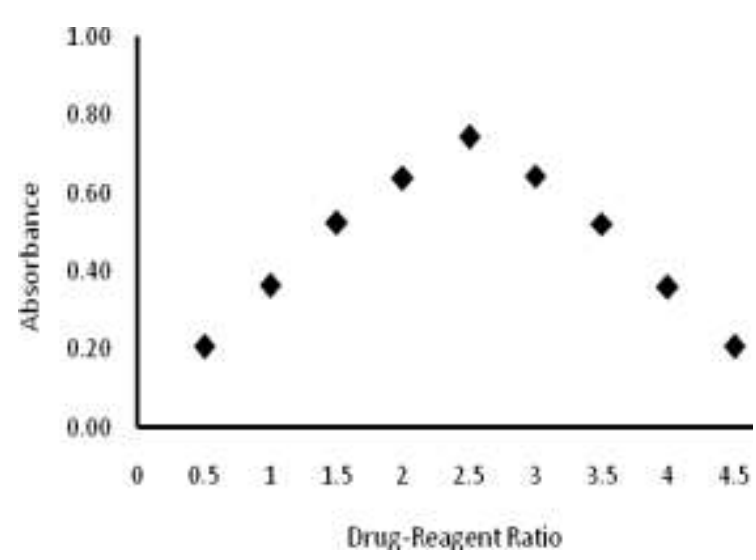

Figure (15): Stoichiometry of The Reaction of Raloxifene $\left(\left(.2^{\circ} \times 10^{-i} \mathrm{M}\right)\right.$ with eosin $-\mathrm{Y}$ $\left(1.2^{\circ} \times 10^{-5} \mathrm{M}\right)$ by Continuous Variation (Job's) Method at $54^{\circ} \mathrm{nm}$. 


\section{The last method E (Ion-Pair Technique with BTB ):}

At a selected $\mathrm{pH}$ value, some basic compounds form ion association complexes on treatment with acid dyes. These complexes are often coloured and extractable in organic solvents to be measured spectrophotometerically. This property is applied for determination of RLX through measurement of the absorbance of the formed yellow coloured complex at $420 \mathrm{~nm}$ using BTB (figure 16). The mechanism of the reaction was illustrated in the following scheme:

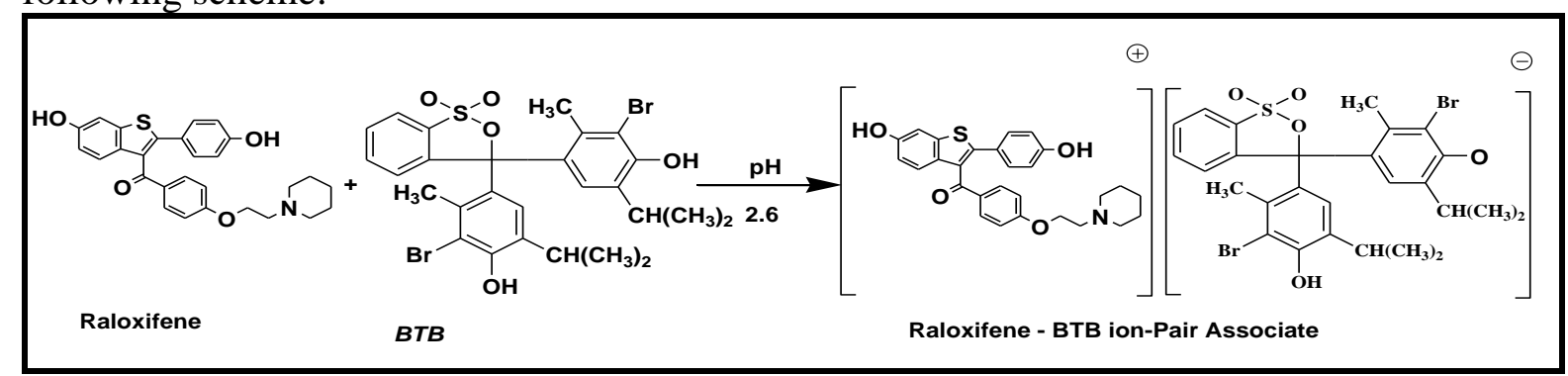

Various parameters affecting the reaction process were studied. The effect of time was studied by allowing the reactants to stand for different times up to one hour, the product was extracted with chloroform and the absorbance was measured at the suggested wavelength. The results reveal that the complex is formed at once producing maximal intensity. In order to establish the optimum $\mathrm{pH}$, the drug was allowed to react with BTB in aqueous solutions buffered to different $\mathrm{pH}$ values, then the complex formed was extracted with chloroform and the absorbance was measured at the corresponding $\lambda_{\max }$, maximum absorbance was obtained upon using potassium acid phthalate buffer solution of $\mathrm{pH} 2.6$ (figure 17). Also the volume of the buffer was optimized to be $4 \mathrm{ml}$ (figure 18).

The drug was allowed to react with different volumes of the dye solution $(0.1 \%)$ and it was found that $3 \mathrm{ml}$ of BTB was sufficient to attain maximum absorbance (figure 19).

Also, some organic solvents e.g. chloroform, methylene chloride, ethylene chloride and carbon tetrachloride were applied for extraction of the complex. It was found that chloroform is the ideal solvent for extracting the formed complex, yielding maximum absorbance intensity (figure 20). Shaking time of about 1 minute, produced a constant absorbance. The absorbance of the separated extract was stable for more than one hour.

Molar ratio method was applied to determine of stoichiometry of the reaction between the drug and the acidic dye. Results reveal a 1:1 complexation ratio under the optimum conditions attained for the reaction between RLX and BTB (figure 21).

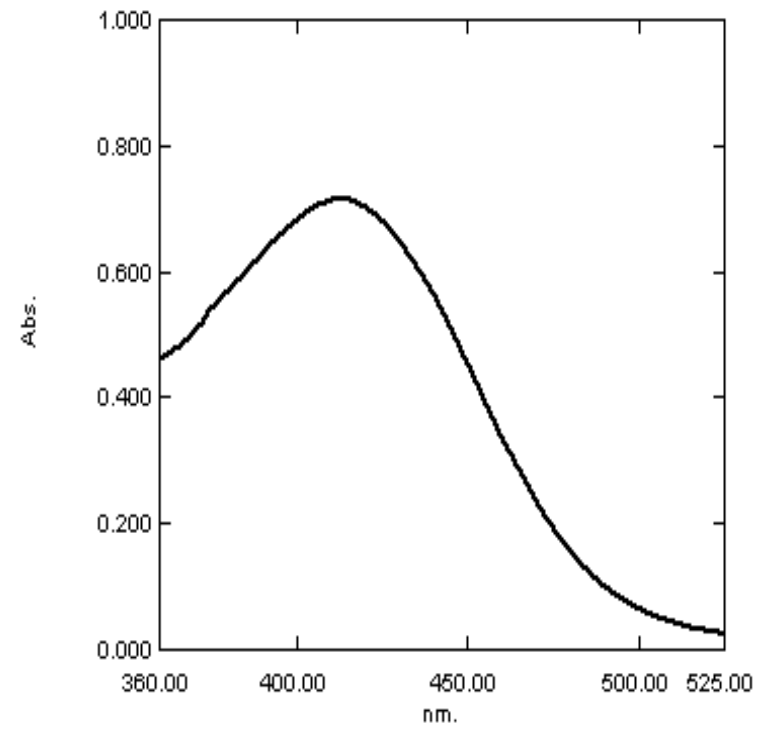

Figure (16): Absorption Spectrum of Raloxifene $\left(20 \mu \mathrm{gml}^{-1}\right)$ Reaction Product with $3 \mathrm{ml}$ BTB Dye.

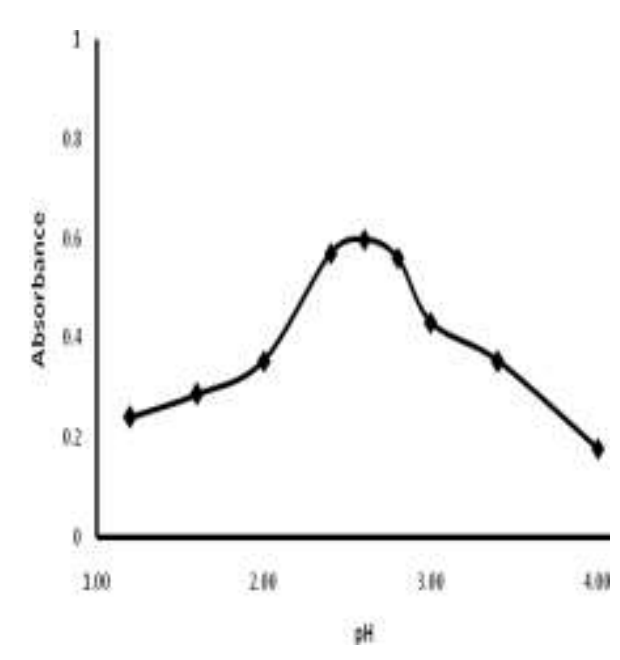

Figure(17): Effect of $\mathrm{pH}$ on The Absorbance of Raloxifene ( $20 \mu \mathrm{g} \mathrm{m} \mathrm{ml}^{-1}$ ) Reaction Product with BTB Dye at $420 \mathrm{~nm}$. 


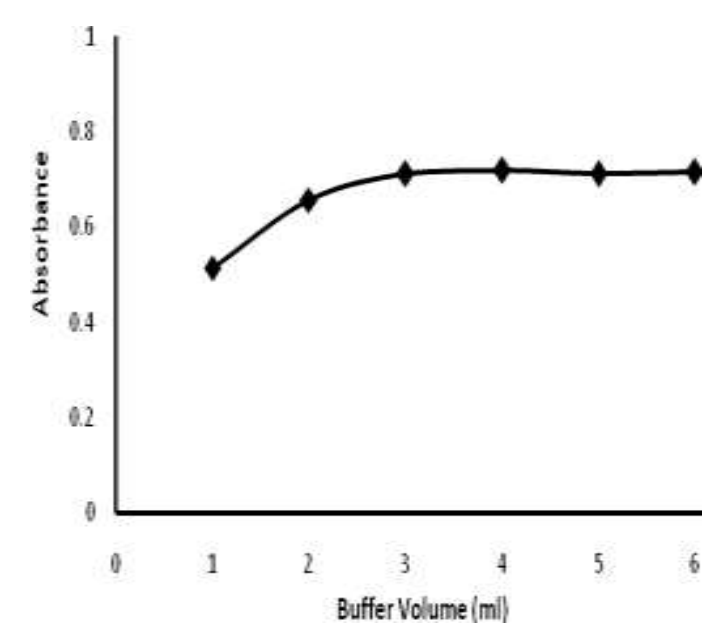

Figure (18): Effect of Buffer Volume on the absorbance of Raloxifene $\left(20 \mu \mathrm{g} \mathrm{ml}^{-1}\right)$ Reaction Product with BTB Dye at $420 \mathrm{~nm}$.

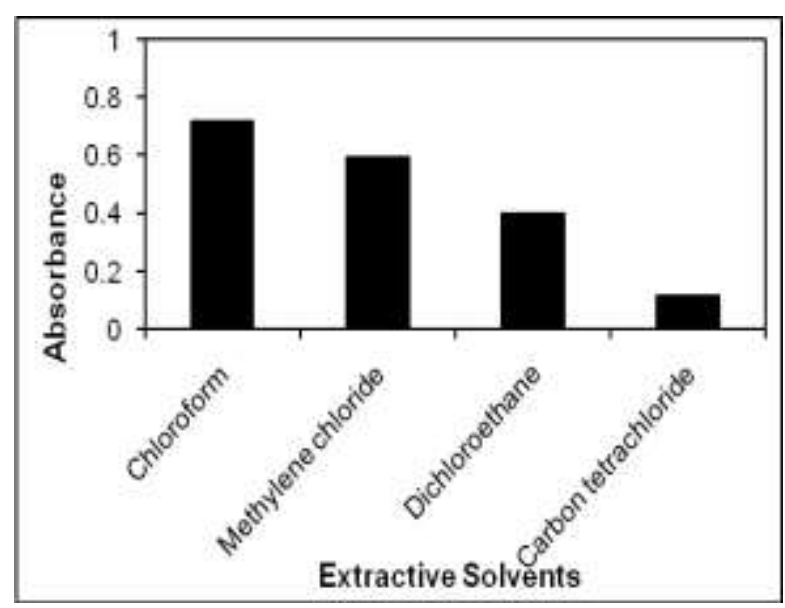

Figure (20): Effect of Extractive Solvenst on The Absorbance of Raloxifene $\left(20 \mu \mathrm{g} \mathrm{ml}^{-1}\right)$ Reaction Product with BTB Dye at $420 \mathrm{~nm}$.

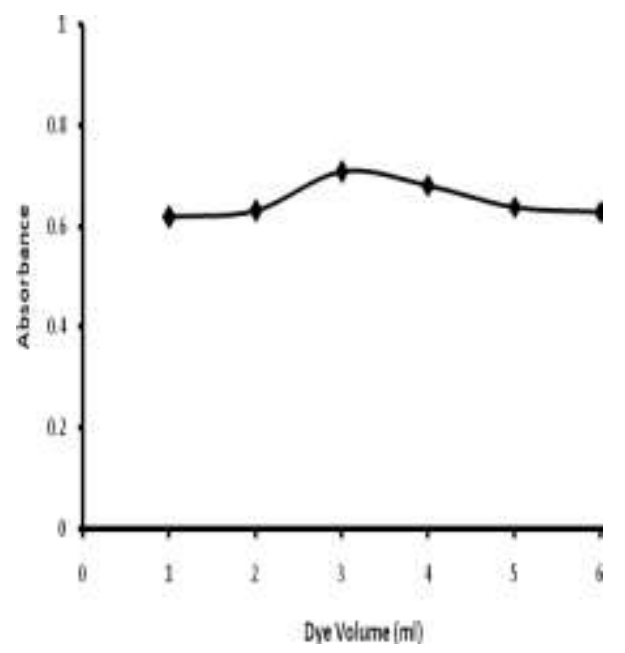

Figure (19): Effect of BTB Dye Volume on The Absorbance of Raloxifene $\left(20 \mu \mathrm{g} \mathrm{ml}^{-1}\right)$ Reaction Product at $420 \mathrm{~nm}$.

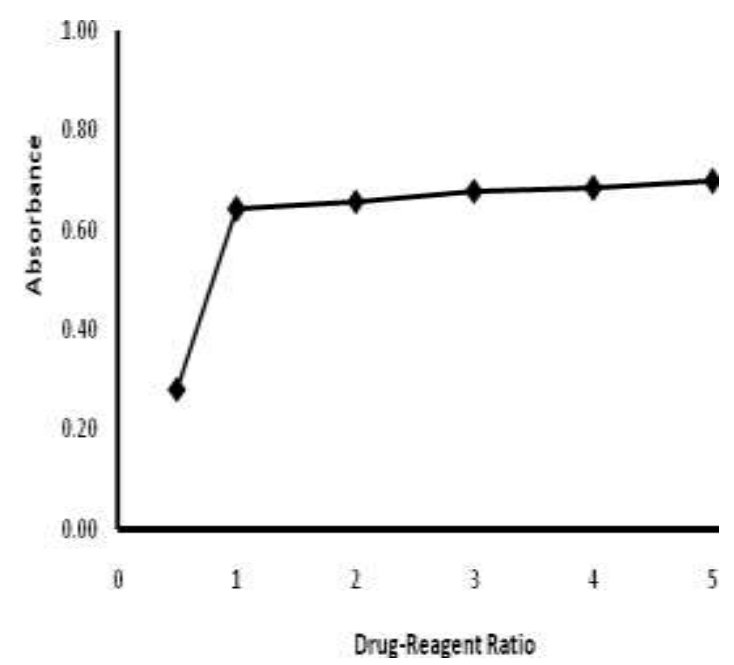

Figure (21): Stoichiometry of the Reaction of Raloxifene $\left(9.8 \times 10^{-4} \mathrm{M}\right)$ with BTB Dye $\left(9.8 \times 10^{-4} \mathrm{M}\right)$ by Molar Ratio Method at420nm.

\section{Validation of the procedures:}

\section{Linearity:}

The linearity range for method $\mathbf{A}$, under the optimized conditions, a linear relationship between the peak area ratio and the corresponding drug concentrations was obtained over the range of $0.5-8 \mu \mathrm{g} \mathrm{ml}^{-1}$. While in methods $\mathbf{B}, \mathbf{D}$ and $\mathbf{E}$ the linearity ranges of the absorbances and the corresponding concentrations were in the range of $3-27,2-20$ and 4-28 $\mu \mathrm{g} \mathrm{ml}^{-1}$, respectively. Also for method $\mathbf{C}$, the linearity range of peak height in $\mathrm{cm}$ and corresponding drug concentrations was in the range of $3-18 \mu \mathrm{g} \mathrm{ml}^{-1}$.

\section{LOD and LOQ:}

The LOD and LOQ were assessed using the slope of the calibration curve and the standard deviation of the blank, table (1).

\section{Accuracy and precision:}

Intraday and interday of the proposed procedures were calculated, table (5) revealed the results of the developed methods. 


\section{Stability of standard drug solution}

The stability of RLX solutions were evaluated by analysis of the stock solution for each procedure. for method $\mathbf{A}$, it was found to be stable for 5 days at room temperature and 8 days if stored in refrigerator. While in method B, it was found to be stable for 4 days either at room temperature or in refrigerator. Also, for methods $\mathbf{C}, \mathbf{D}$ and $\mathbf{E}$, it was found to be stable for more than 7 days at room temperature and in refrigerator.

\section{System suitability:}

System suitability test for method A was applied to a representative chromatogram to check various parameters such as the number of theoretical plates $(\mathrm{N})$, resolution factor $(\mathrm{R})$, capacity factor $\left(\mathrm{K}^{-}\right)$, tailing factor $(\mathrm{T})$ and selectivity factor $(\alpha)$. The results obtained revealed that the chromatographic conditions described here allow complete base line separation between drug, its degradate and the internal standard peaks with minimum tailing.

\section{Ruggedness:}

The proposed HPLC procedure was evaluated using different sources of acetonitrile; Sigma; Aldrich, LabScan, Scharlau. The RSD\% was found to be 1.46 proving ruggedness of the procedure.

\section{Robustness:}

The robustness of the proposed HPLC procedure was evaluated by the introduction of intentional variation in the mobile phase contents ratios. It was found that, using $49-51 \mathrm{ml}$ of $0.05 \mathrm{M} \mathrm{KH}_{2} \mathrm{PO}_{4}$ did not affect the system suitability parameters, confirming robustness of the procedure.

\section{Analysis of pharmaceutical preparation}

The proposed procedures were also adopted for the determination of RLX in Evista ${ }^{\circledR}$ $60 \mathrm{mg}$ tablets. It should be pointed out that no interference by excipients and additives in Evista $^{\circledR} 60 \mathrm{mg}$ tablets. The recovery of the proposed procedures was determined by applying standard addition technique table (6).

The results obtained by the proposed procedures were statistically compared with those obtained by the reported one depending on the UV absorbance in $0.1 \mathrm{M} \mathrm{NaOH}$ (Pavithra DC and Lakshmi SS. 2006 ). The calculated " $t$ " and " $F$ " values are less than tabulated ones confirming accuracy and precision at $95 \%$ confidence limits table (7).

\section{CONCLUSION}

Simple, accurate and precise methods were developed for the analysis of raloxifene hydrochloride in pure form and its tablets. The sensitivity, reproducibility and simplicity of the proposed methods makes it valuable in routine analysis of raloxifene hydrochloride. In addition, some of the proposed methods mainly, HPLC, $\triangle \mathrm{A}$ and first derivative methods were found to be stability - indicating methods. This offer an advantage over the published methods. 
Table (1):_Selected spectral data for the determination of (RLX) by the proposed procedures:

\begin{tabular}{|c|c|c|c|c|c|}
\hline Method & $\bar{A}$ & $B$ & $C$ & $D$ & $E$ \\
\hline$\lambda_{\max } \mathbf{n m}$ & 280 & 285 & 268 & 545 & 420 \\
\hline $\begin{array}{c}\text { Linearity range } \\
\left(\mu \mathrm{gml}^{-1}\right)\end{array}$ & $0.5-8$ & $3-27$ & $3-18$ & $2-20$ & $4-28$ \\
\hline $\operatorname{LOD}\left(\mu \mathrm{gml}^{-1}\right)$ & 0.077 & 0.233 & 0.254 & 0.276 & 0.633 \\
\hline LOQ $\left(\mu g^{-1}\right)$ & 0.258 & 0.778 & 0.849 & 0.920 & 2.110 \\
\hline $\begin{array}{c}\begin{array}{c}\text { Working range } \\
\left(\mu \mathrm{gml}^{-1}\right)\end{array} \\
\end{array}$ & $0.5-8$ & $3-27$ & $3-18$ & $2-20$ & $4-28$ \\
\hline $\begin{array}{c}\text { Response factor } \\
\pm \text { SD }\end{array}$ & $0.353 \pm 0.013$ & $0.036 \pm 0.073$ & $0.084 \pm 0.008$ & $0.053 \pm 0.006$ & $0.038 \pm 0.014$ \\
\hline $\mathrm{A}(1 \%, 1 \mathrm{~cm})$ & 4533 & 353 & 2133 & 526 & 376 \\
\hline $\begin{array}{c}\text { Regression } \\
\text { Parameters } \\
\text { - Slope } \pm S . D\end{array}$ & $0.353 \pm 9.8 \times 10^{-3}$ & $0.035 \pm 7.4 \times 10^{-2}$ & $0.052 \pm 1.6 \times 10^{-3}$ & $0.050 \pm 1.15 \times 10^{-4}$ & $0.039 \pm 2.3 \times 10^{-3}$ \\
\hline -Intercept \pm S.D & $0.081 \pm 8.9 \times 10^{-2}$ & $0.009 \pm 3.7 \times 10^{-2}$ & $0.095 \pm 4.4 \times 10^{-3}$ & $0.014 \pm 4.5 \times 10^{-3}$ & $-0.017 \pm 2.6 \times 10^{-3}$ \\
\hline $\begin{array}{c}\text { Correlation } \\
\text { Coefficient }\left(\mathbf{r}^{2}\right) \\
\end{array}$ & 0.9998 & 0.9998 & 0.9998 & 0.9999 & 0.9999 \\
\hline
\end{tabular}

Table ( 2 ): Determination of (RLX) in Mixtures with its Degradation Product by the Proposed HPLC Procedure:

\begin{tabular}{|c|c|c|c|c|}
\hline $\begin{array}{c}\text { Intact } \\
\text { in }\left(\mu \mathrm{g} \mathrm{ml}^{-1}\right) \\
\end{array}$ & $\begin{array}{l}\text { Degradate } \\
\text { in }\left(\mu \mathrm{g} \mathrm{ml}^{-1}\right)\end{array}$ & $\begin{array}{l}\text { Percent of } \\
\text { degradate }\end{array}$ & $\begin{array}{c}\text { Intact found } \\
\text { in }\left(\mu \mathrm{g} \mathrm{ml}^{-1}\right)\end{array}$ & $\begin{array}{c}\text { Recovery \% } \\
\text { of intact }\end{array}$ \\
\hline 7 & 1 & 12.5 & 7.12 & 101.71 \\
\hline 6 & 2 & 25 & 6.1 & 101.67 \\
\hline 5 & 3 & 37.5 & 5.08 & 101.60 \\
\hline 4 & 4 & 50 & 3.95 & 98.75 \\
\hline 3 & 5 & 62.5 & 2.98 & 99.33 \\
\hline 2 & 6 & 75 & 1.99 & 99.50 \\
\hline 1 & 7 & 87.5 & 1 & 100.00 \\
\hline Mean \pm SD & & & & $100.37+1.260$ \\
\hline
\end{tabular}

Table ( 3 ): Determination of (RLX) in Mixtures with its Degradation Product by the Proposed $\Delta \mathrm{A}$ Procedure:

\begin{tabular}{|c|c|c|c|c|}
\hline $\begin{array}{c}\text { Intact } \\
\text { in }\left(\boldsymbol{\mu g} \mathbf{~ m l}^{\mathbf{1}}\right)\end{array}$ & $\begin{array}{c}\text { Degradate } \\
\text { in }\left(\boldsymbol{\mu g} \mathbf{~ m l}^{\mathbf{1}}\right)\end{array}$ & $\begin{array}{c}\text { Percent of } \\
\text { degradate }\end{array}$ & $\begin{array}{c}\text { Intact found } \\
\text { in }\left(\boldsymbol{\mu g} \mathbf{~ m l}^{\mathbf{1}}\right)\end{array}$ & $\begin{array}{c}\text { Recovery \% } \\
\text { of intact }\end{array}$ \\
\hline 24 & 3 & 11.1 & 24.13 & 100.54 \\
\hline 21 & 6 & 22.2 & 21.16 & 100.76 \\
\hline 18 & 9 & 33.3 & 18.1 & 100.56 \\
\hline 15 & 12 & 44.4 & 15.06 & 100.40 \\
\hline 12 & 15 & 55.5 & 11.96 & 99.67 \\
\hline 9 & 18 & 66.6 & 8.91 & 99.00 \\
\hline 6 & 21 & 77.7 & 5.95 & 99.17 \\
\hline Mean \pm SD & \multicolumn{4}{|l}{} \\
\hline
\end{tabular}


Table (4): Determination of (RLX) in Mixtures with its Degradation Product by the Proposed First Derivative $\left({ }^{1} \mathrm{D}\right)$ procedure:

\begin{tabular}{|c|c|c|c|c|}
\hline $\begin{array}{c}\text { Intact } \\
\left(\boldsymbol{\mu} \mathbf{~ m l}^{\mathbf{1}}\right)\end{array}$ & $\begin{array}{c}\text { Degradate } \\
\left(\boldsymbol{\mu} \mathbf{~ m l}^{\mathbf{1}}\right)\end{array}$ & Degradate \% & $\begin{array}{c}\text { Intact found } \\
\left(\boldsymbol{\mu} \mathbf{~ m l}^{-\mathbf{1}}\right)\end{array}$ & $\begin{array}{c}\text { Recovery \% } \\
\text { of Intact }\end{array}$ \\
\hline 16 & 2 & 11.1 & 16.16 & 101.00 \\
\hline 14 & 4 & 22.2 & 14.10 & 100.71 \\
\hline 12 & 6 & 33.3 & 12.03 & 100.25 \\
\hline 10 & 8 & 44.4 & 10.15 & 101.50 \\
\hline 8 & 10 & 55.5 & 7.97 & 99.63 \\
\hline 6 & 12 & 66.6 & 5.95 & 99.17 \\
\hline 4 & 14 & 77.7 & 3.98 & 99.50 \\
\hline 2 & 16 & 88.8 & 2.01 & 100.50 \\
\hline Mean \pm SD & \multicolumn{3}{|l}{} \\
\hline
\end{tabular}

Table (5): Intraday and interday accuracy and precision for the determination of RLX by the proposed procedures:

\begin{tabular}{|c|c|c|c|c|c|c|c|}
\hline \multirow{2}{*}{ Method } & \multirow{2}{*}{$\begin{array}{l}\text { Conc. } \\
\mu g m l^{-1}\end{array}$} & \multicolumn{3}{|c|}{ Intraday } & \multicolumn{3}{|c|}{ Interday } \\
\hline & & $\begin{array}{c}\text { Found } \\
\text { Conc. }+S D\end{array}$ & $\begin{array}{c}\text { Accuracy } \\
(\mathrm{R} \%)\end{array}$ & $\begin{array}{c}\text { Precision } \\
(\text { RSD\% })\end{array}$ & $\begin{array}{c}\text { Found } \\
\text { Conc. } \pm S D\end{array}$ & $\begin{array}{c}\begin{array}{c}\text { Accuracy } \\
(\boldsymbol{R} \%)\end{array} \\
\end{array}$ & $\begin{array}{c}\text { Precision } \\
(\text { RSD\% })\end{array}$ \\
\hline \multirow{3}{*}{$\begin{array}{c}\text { Method } \\
\text { A }\end{array}$} & $r$ & $2.02 \pm 0.018$ & 101.00 & 0.891 & $2.00 \pm 0.060$ & 100.00 & 0.500 \\
\hline & $\varepsilon$ & $4.05 \pm 0.039$ & 101.25 & 0.963 & $3.96 \pm 0.062$ & 99.00 & 1.566 \\
\hline & 7 & $5.98 \pm 0.070$ & 99.67 & 1.171 & $5.96 \pm 0.054$ & 99.33 & 0.906 \\
\hline \multirow{3}{*}{$\begin{array}{c}\text { Method } \\
\text { B }\end{array}$} & 6 & $5.98 \pm 0.021$ & 99.67 & 0.351 & $6.07 \pm 0.031$ & 101.17 & 0.511 \\
\hline & 12 & $12.15 \pm 0.025$ & 101.25 & 0.206 & $11.98 \pm 0.019$ & 99.83 & 0.159 \\
\hline & 24 & $24.00 \pm 0.031$ & 100.00 & 0.129 & $23.99 \pm 0.018$ & 99.96 & 0.075 \\
\hline \multirow{3}{*}{$\begin{array}{c}\text { Method } \\
\text { C }\end{array}$} & 7 & $6.10 \pm 0.012$ & 101.67 & 0.197 & $5.99 \pm 0.020$ & 99.83 & 0.334 \\
\hline & 9 & $9.10 \pm 0.070$ & 101.11 & 0.769 & $8.98 \pm 0.036$ & 99.78 & 0.401 \\
\hline & Ir & $11.97 \pm 0.690$ & 99.75 & 0.576 & $12.05 \pm 0.065$ & 100.42 & 0.539 \\
\hline \multirow{3}{*}{$\begin{array}{c}\text { Method } \\
\text { D }\end{array}$} & 7 & $6.05 \pm 0.015$ & 100.83 & 0.248 & $5.94 \pm 0.016$ & 99.00 & 0.269 \\
\hline & 1. & $10.15 \pm 0.018$ & 101.50 & 0.177 & $9.90 \pm 0.030$ & 99.00 & 0.303 \\
\hline & $1 \varepsilon$ & $13.91 \pm 0.026$ & 99.36 & 0.187 & $14.10 \pm 0.038$ & 100.71 & 0.270 \\
\hline \multirow{3}{*}{$\begin{array}{c}\text { Method } \\
\text { E }\end{array}$} & TY & $12.17 \pm 0.027$ & 101.42 & 0.222 & $11.98 \pm 0.019$ & 99.83 & 0.159 \\
\hline & 17 & $16.22 \pm 0.041$ & 101.38 & 0.253 & $16.20 \pm 0.012$ & 101.25 & 0.074 \\
\hline & r. & $19.92 \pm 0.034$ & 99.60 & 0.171 & $19.99 \pm 0.029$ & 99.95 & 0.145 \\
\hline
\end{tabular}


Table (6): Application of standard addition technique for the determination of RLX in its pharmaceutical preparation (Evista ${ }^{\circledR}$ tablets) by the proposed producers:

\begin{tabular}{|c|c|c|c|c|}
\hline & $\begin{array}{l}\text { Claimed taken } \\
\qquad\left(\mu \mathrm{gml}^{-1}\right)\end{array}$ & $\begin{array}{l}\text { Pure added } \\
\left(\mu \mathrm{gml}^{-1}\right)\end{array}$ & $\begin{array}{l}\text { Pure found } \\
\left(\mu \mathrm{gml}^{-1}\right)\end{array}$ & $\begin{array}{l}\text { Recovery } \% \text { of } \\
\text { pure found }\end{array}$ \\
\hline \multirow{5}{*}{ Method A } & 2 & 6 & 5.98 & 99.67 \\
\hline & 3 & 5 & 4.94 & 98.80 \\
\hline & 4 & 4 & 4.05 & 101.25 \\
\hline & 5 & 3 & 3.05 & 101.67 \\
\hline & 6 & 2 & 2.00 & 100.00 \\
\hline Mean & & & & 100.28 \\
\hline RSD\% & & & & 1.17 \\
\hline \multirow{4}{*}{ Method B } & \multirow{4}{*}{3} & 6 & 6.10 & 101.67 \\
\hline & & 12 & 12.17 & 101.42 \\
\hline & & 18 & 17.90 & 99.44 \\
\hline & & 24 & 23.98 & 99.92 \\
\hline Mean & & & & 100.61 \\
\hline $\mathrm{RSD} \%$ & & & & 1.09 \\
\hline \multirow{4}{*}{ Method C } & \multirow{4}{*}{6} & 3 & 3.01 & 100.33 \\
\hline & & 6 & 6.04 & 100.67 \\
\hline & & 9 & 8.96 & 99.56 \\
\hline & & 12 & 12.15 & 101.25 \\
\hline Mean & & & & 100.45 \\
\hline RSD\% & & & & 0.70 \\
\hline \multirow{4}{*}{ Method D } & \multirow{4}{*}{4} & 4 & 4.04 & 101.00 \\
\hline & & 8 & 8.07 & 100.88 \\
\hline & & 12 & 12.13 & 101.08 \\
\hline & & 16 & 15.94 & 99.63 \\
\hline Mean & & & & 100.65 \\
\hline $\mathrm{RSD} \%$ & & & & 0.68 \\
\hline \multirow{4}{*}{ Method E } & \multirow{4}{*}{8} & 8 & 7.93 & 99.13 \\
\hline & & 12 & 12.13 & 101.08 \\
\hline & & 16 & 16.15 & 100.94 \\
\hline & & 20 & 19.89 & 99.45 \\
\hline Mean & & & & 100.15 \\
\hline $\mathrm{RSD} \%$ & & & & 1.00 \\
\hline
\end{tabular}


Table (7): Statistical analysis of results obtained by the proposed and reported methods for the determination of RLX in its pharmaceutical preparation:

\begin{tabular}{|c|c|c|c|c|c|c|}
\hline & \multicolumn{6}{|c|}{ Evista $^{\circledR}$ Tablets } \\
\hline Method & $\mathbf{A}$ & B & $\mathbf{C}$ & D & $\mathbf{E}$ & $\begin{array}{l}\text { Reported } \\
\text { method }\end{array}$ \\
\hline$N^{* *}$ & 7 & 9 & 8 & 7 & 8 & 5 \\
\hline Mean & $100 . \wedge \Gamma$ & $100 . \Upsilon 4$ & 100.10 & $100 . Y^{4}$ & 99.91 & $99 . \wedge 9$ \\
\hline SD & 0.920 & $0 . \vee r 4$ & $0.0 \wedge 6$ & $0 . \Gamma \wedge 3$ & $\because r 71$ & 0.750 \\
\hline$R S D \%$ & 0.920 & $0 . \vee Y 4$ & 0.086 & $0 . r \wedge 3$ & $\cdot r 71$ & 0.750 \\
\hline $\mathbf{t}^{* * *}$ & $\begin{array}{l}1.01 Y \\
(2.228)\end{array}$ & $\begin{array}{l}0 . \wedge 70 \\
(2.179)\end{array}$ & $\begin{array}{c}1.1 \leq 7 \\
(2.201)\end{array}$ & $\begin{array}{c}0.9 \wedge \vee \\
(2.228)\end{array}$ & $\begin{array}{l}1.199 \\
(2.201)\end{array}$ & \\
\hline $\mathbf{F}^{* * * *}$ & $\begin{array}{c}1 . r \wedge \\
(6.16)\end{array}$ & $\begin{array}{c}4.97 \\
(6.04)\end{array}$ & $\begin{array}{l}1.90 \\
(6.09)\end{array}$ & $\begin{array}{c}r .2^{\circ} \\
(6.16)\end{array}$ & $\begin{array}{l}r .19 \cdot \\
(6.09)\end{array}$ & \\
\hline
\end{tabular}

* UV absorbance in acidic medium(Pavithra DC and Lakshmi SS.2006).

** Number of experimental.

*** The values in parenthesis are tabulated values for " $\mathrm{t}$ " and " $\mathrm{F}$ " at $\mathrm{P}<0.05$

\section{REFERENCES}

Annapurna MM; Bhanoji Rao ME and Ravikumar VV. (2007): E -Journal of Chemistry; 4: 79-82.

Attia KAM; Amin MA; Ibrahim MW and Morshedy SM. (2009): Bull.Fac.pharm. Cairo Univ., 47 (1) $181-191$.

Attia KAM; Amin MA; Ibrahim MW and Morshedy SM. (2009): Egypt. J. pharm. Sci. 50; 57 - 79.

Basavaiah K and Anil Kumar UR. (2006): E- Journal of Chemistry; 3(13): 242-249.

Basavaiah K; Anil Kumar UR and Tharpa K. (2008): Acta Pharmaceutica; 58(3): 347-356.

Basavaiah K; Anil Kumar UR; Tharpa K and Vinay KB. (2009): Chemical Ind. \& Chemical Eng Quarterly; 15(3): 119-123.

Basavaiah K; Anil Kumar UR; Tharpa K and Vinay KB. (2008): J. Chilean Chem. Soc., 53(3): 1635-1639.

Basavaiah K; Anil Kumar UR; Tharpa K; Nagaraju RP; Ganeshbhat SH and Vinay KB. (2009): Archives of Pharmaceutical Research; 32(9):1271-1279.

British Pharmacopoeia, (2001): Vol. I and II international Ed., the stationary office, London.

Chandorkar JG; Pande VV; Pande SV and Dongare MK. (2006): Indian Drugs; 43(7):561 - 564.

Dharuman J; Ravichandran V; Thirumoorthy N and Dharamsi A. (2004): Pharmazie; 59: 720-721.

El-Brashy A M; Metwally M E and El-Sepai F A. (2004): IL FARMACO, 59: 809 - 817.

Jin Y. Huaxue Gongye Yu Gongcheng Jishu., (2004): Through Chemical Abstract, 144 (2005) 25: $56-57$.

Kalyanaramu B and Raghubabu K. (2011): J. Chem. Pharm. Res.,; 3(1): 122-127.

Kalyanaramu B. and Raghubabu K. (2011): Int. J. Curr. Pharm. Res., 3; 62 - 64.

Kalyanaramu B. and Raghubabu K. (2011): Int.J.Analyt. and Bioanalyt.Chem. 1(2):29 - 33.

Kalyanaramu B. Raghubabu K.; Vamsikumar Y. and Jagannadharao V., J. Der Pharma chemica 3(2) $250-256(2011)$.

Li F; Shao-pu L; Da-cheng Y and Xiao-Li H. (2002): Chin J Chem.,; 20: 1552-1556. 
Madhu B.; Anilkumar A.; Prashanth S.; Pradeep Kumar Y.; Raju J.; Ramesh G.; Madhusudan RY and Jayaveera KN.; (2011): J Pharmacy Research 4(3), 582 - 584.

Martindale the complete drug reference CD.

Nandini P and Jayant W. (2001): Indian Drugs; 38: 591- 592.

Patel PM; Patel RC and Patel NM. (2007): Indian Drugs; 44(11): 841-842.

Pavithra DC and Lakshmi SS. (2006): Indian J Pharm. Sci., 68(3): 375-376.

Pavithra DC and Lakshmi SS. (2006): Indian J Pharm. Sci.,; 68: 401- 402.

Perez-Ruiz T; Martinez-Lozano C; Sanz A and Bravo E. (2004): J Pharm. Biomed Anal; 34: 891-897.

Santhyaraj A.; satyanarayana V. and Basaveswara RMV. (2011): Res. J. Chem. Sci. 1 (2): 9 - 14.

Shao PL; You QH, Zhong FL, Ling K and Qun ML. (2007): Analytica Chimica Acta 598, 304 311.

Shirkhedkar AA.; Rajput JK; Rajput DK and Surana SJ. (2012): Chromat. Res. International Vol. 201:1- 7 .

Suneetha P and Lakshmana Rao A A. (2010): Rasayan J. of Chem., 3(1): 117-121.

The Merck index $14^{\text {th }}$ Ed. (2006): Published by Merk and Co. INC., Rahway, USA.

Trontelj J; Vovic T; Bogataj M and Mrhar A. (2007): J Chromatography B; 855(2): 220 - 227.

Trontelj J; Vovic T; Bogataj M and Mrhar A. (2005): Pharm. Res., 52(4): 334 - 339.

Turij T; Marija B; Janja M and Ales M. (2007): Chroma. J.B. 855: 220 - 227.

Turij T; Tomaz V; Marija B and Ales M. (2005): Pharm. Research 32 : 334 - 339.

United States Pharmacopoeia XXIII, (1995): United States Pharmacopoeia convention.

Venkata RP; Sudha RB; Srinibabu G and Seshsgiri RJ. (2006): European J of Chemistry; 3: 60 64.

Vijaykumar B; Partapkumar K; Suresh K.; Saheena A.; Srikanth P. and Suneetha Y., (2011): J. Chem. Pharm. Res. 3(3), $784-791$.

Wang Q, Zhang $H$ and Yu Z. (2002): Shenyang Yaoke Daxue Xuebao 19: 105-108. Through Chemical Abstract, 137.

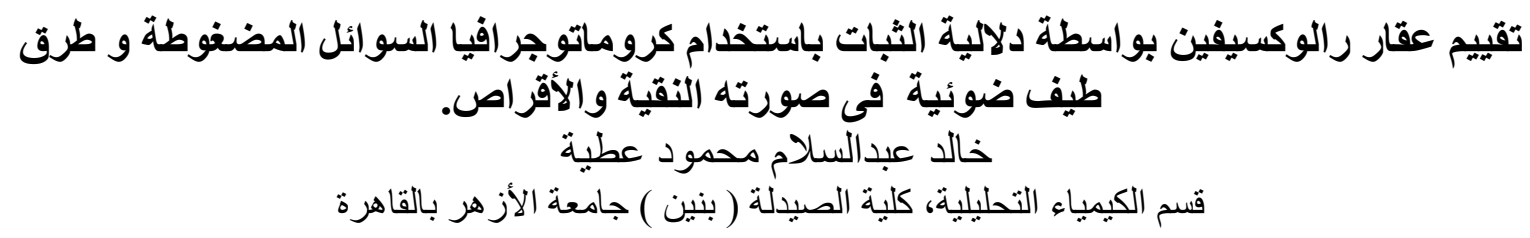

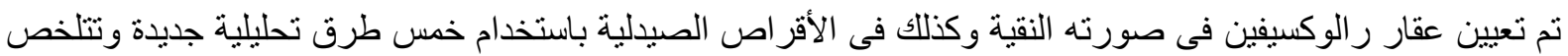

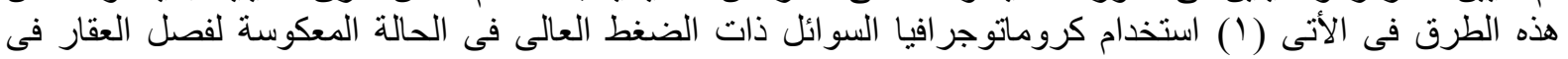

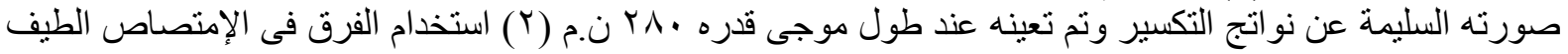

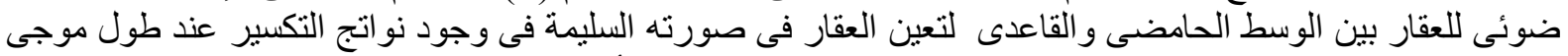

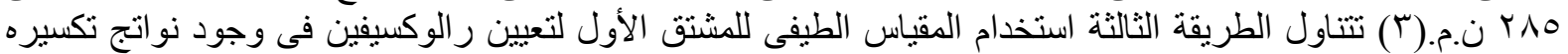

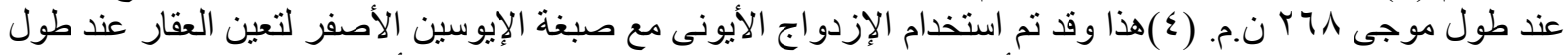

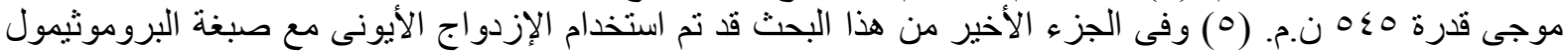

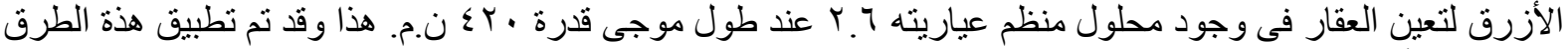
فى تحليل الأقر اص وبمقارنة هذة الطرق إحصائيا بالطريقة المنشورة لم يكن هناك فرق بـان بينهم. 